\title{
Výběr z nových publikací v oborové knihovně Centra pro prezentaci kulturního dědictví
}

Michaela Smidová

Oborová knihovna Centra pro prezentaci kulturního dědictví se od svého založení v roce 2005 etabluje jako jedinečný knižní zdroj pro oblast muzeologie v České republice. Cílem knihovny je umožnit muzejníkům, ale také studenti̊m a pracovníkìm v oblasti kultury, vzděláváni a př́buzných odvětvi př́stup $k$ aktuálním písemným pramenům a přehledovým titulüm $z$ domácího $i$ zahraničního prostředí. V současnosti její fond čítá téměř 1800 knih z různých oblastí muzejní práce - muzejni teorie, správy sbirek, pedagogiky, tvorby výstav, péče o sbirky nebo práce s veřejností. V knihovně můžeme nalézt také publikace zabývajici se tématem architektury, managementu, marketingu nebo digitálních technologií ve vztahu $k$ movitému kulturnímu dědictví, ale také nová $i$ archivní čísla nejoýznamnějších domácích i zahraničních muzejních periodik. Kompletni katalog knihovny s možností vyhledáváni je př́stupný na webovém portálu emuzeum.cz. Knižni fond byl $i$ v roce 2018 doplněn o několik desitek nejnovějších domácích a zahraničních publikací.

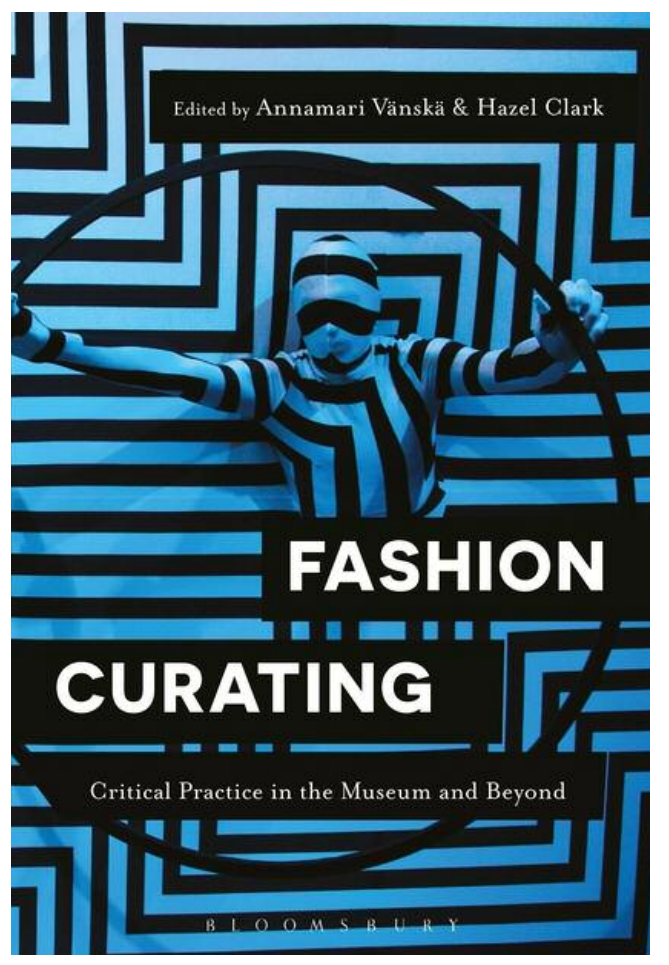

\section{FASHION CURATING: Critical}

Practise in the Museum and beyond CLARK, Hazel; VÄNSKÄ, Annamari (editoři)

Publikace složená ze statí vícero autorů se věnuje novým, moderním přístupům ke sbírkám textilu a oděvů, možnostem jejich prezentace v kontextu výstav a expozic nebo jejich využití a potenciálu jako efektivního marketingového prostředku k vyvolání zájmu návštěvníků. Jednotliví odborníci a kurátoři prostřednictvím úspěšných realizovaných projektů představují čtenářum oblast módy, oděvu a textilu z různých úhlů od tvorby konceptu výstav, spolupráci s komerčními subjekty v oblasti módy, specifika instalace či samotnou sbírkotvornou činnost a péči o sbírky. V neposlední řadě se publikace věnuje společenským aspektưm módy a jejího vystavování, jako je přístup k textiliím neevropského původu nebo feministický pohled na tuto problematiku.
Mgr. Michaela Smidová Národní muzeum, Centrum pro prezentaci kulturního dědictví

michaela_smidova@nm.cz 


\section{Public Representations of Immigrants in Museums. Exhibition and Exposure in France and Germany PORSCHÉ, Yannik}

V díle autor sleduje instalace stejného výstavního projektu ve třech muzeích ve Francii a Německu, jehož námětem byly národní identity Francouzů a Němců, jejich vzájemný vztah v moderních dějinách a současnosti, společenský pohled na zakořeněné stereotypy či problematiku imigrace a priistěhovalců v tomto kontextu. Autor si klade otázku, jak se liší jednotlivé instalace krátkodobé expozice $\mathrm{v}$ závislosti na zemi, zaměření muzea od přípravy přes reakce návštěvníků a informace $\mathrm{k}$ projektu $\mathrm{v}$ médiích. Autor se pokouší na základě této př́padové studie najít spojitost mezi institucionální prezentací vlastního národa a pristěhovalců a postojem, který vưči nim zaujímá většinová společnost. Svým tématem utváření veřejného mínění $v$ muzejních institucích je originální publikace velmi aktuální.

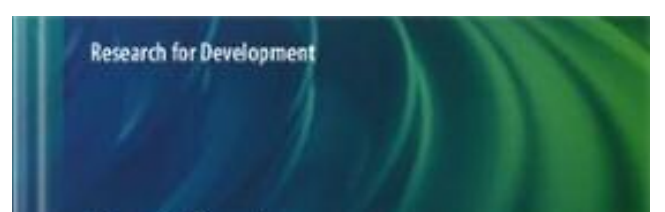

Alberto Rovetta Edoardo Rovida

\section{Scientific Knowledge Communication in Museums}

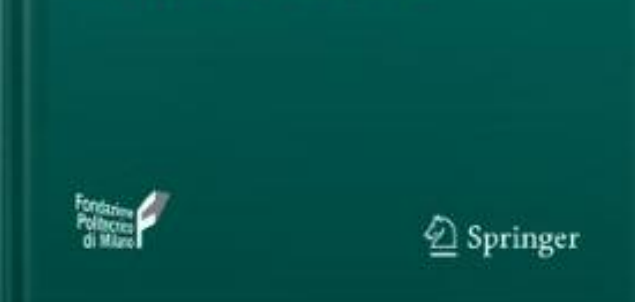

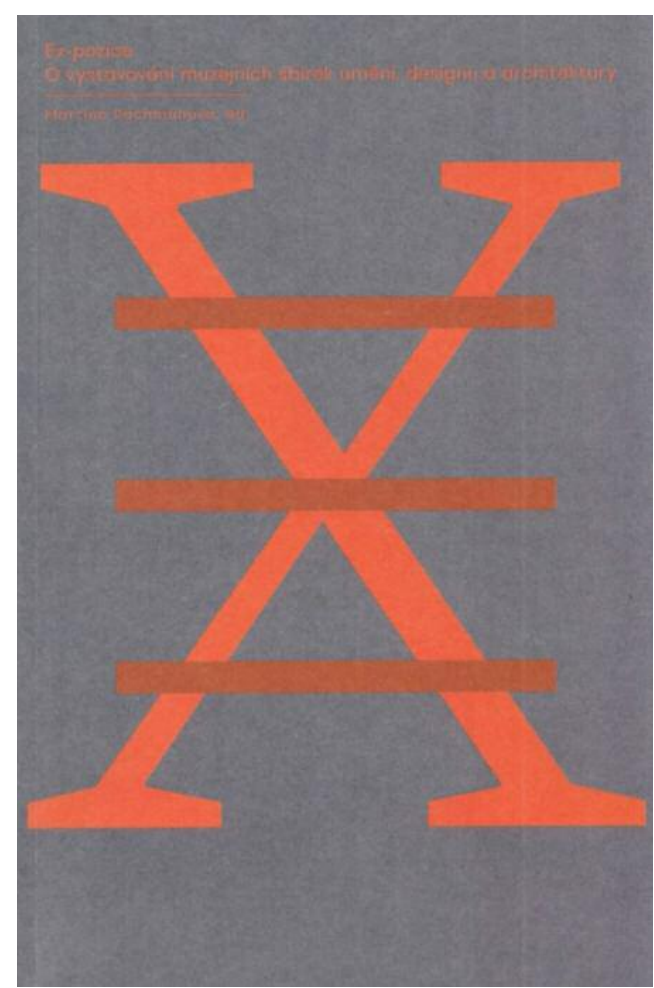

\section{Scientific Knowledge Communication in Museums ROVETTA, Alberto}

Zejména pro pracovníky přírodovědeckých a technických muzeí může být inspirativní nová publikace $\mathrm{z}$ řady Research for Development vydavatelství Springer. Dnešní muzea stojí před nelehkým úkolem předat svým návštěvníkům informace a znalosti ve srozumitelné a poutavé formě. Studie představuje široké spektrum možností předávání informací v muzejním prostředí a specifickou aplikaci těchto postupů $\mathrm{v}$ prostředí př́rodovědecky nebo technicky zaměřených institucí. Kromě tradičně využívaných metod (text ve výstavě, výklad průvodce a další) klade publikace dưraz také na roli moderních technologií $\mathrm{v}$ této oblasti muzejní práce, jako jsou mobilní aplikace, sdílení dat na serverech služby cloud nebo 3D tiskárny. Kromě přírodovědně zaměřených institucí může být kniha přínosná pro všechny pracovníky, kteří se podílí na zprostředkování znalostí a informací v kulturních a vědeckých institucích. 


\section{Ex-pozice: O vystavování muzejních sbírek umění, designu a architektury PACHMANOVÁ, Martina}

Jakkoliv je česká odborná literatura bohatá na přehledová díla o tuzemském umění, teprve v posledních letech vznikají publikace, které se snaží nahlížet na muzea umění jako na místa interdisciplinárního a kritického zkoumání. Sborník, který vznikl pod patronátem Vysoké školy uměleckoprůmyslové v Praze, si klade za cíl poukázat na nové koncepty v muzejní prezentaci uměleckých děl, interpretaci exponátů a umění jako takového. Př́spěvky studentek a studentů Katedry teorie a dějin umění UMPRUM, ale také zahraničních odbornic a odborníků, konfrontují současnou výstavní praxi s aktuálními trendy. Ke slovu se dostávají také aktuální společenské otázky, které začínají být reflektovány i v českém prostředí, jako LGBT+ identity v uměleckých expozicích nebo problém muzejní interpretace soudobých dějin. Prostor dostává také téma stálých a dlouhodobých expozic, které je $\mathrm{v}$ domácí i zahraniční literatuře $\mathrm{k}$ tématu často opomíjeno.

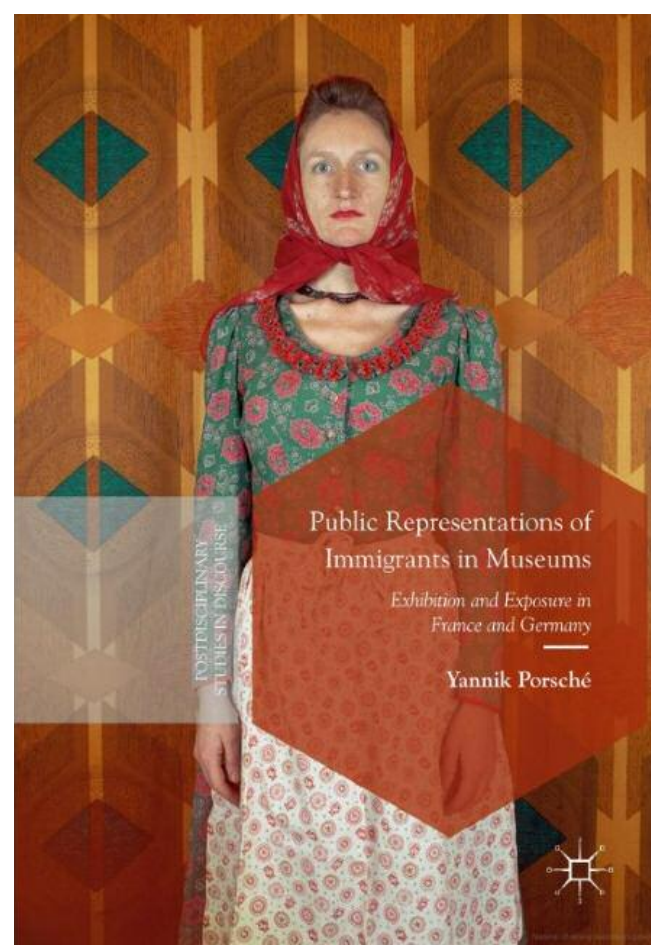

